\title{
Anti-diabetic Activity of the Red Dragon Fruit Peel (Hylocereus polyrhizus) in Ethanol Extract against Diabetic Rats
}

\author{
Ruqiah Ganda Putri Panjaitan*, Novitasari
}

Ruqiah Ganda Putri Panjaitan*, Novitasari

Department of Biology Education, Faculty of Teacher Training and Education, Tanjungpura University. Jl. Prof. Dr. H. Hadari Nawawi, Bansir Laut, Kec. Pontianak Tenggara, Kota Pontianak, West Kalimantan 78124, INDONESIA.

\section{Correspondence}

Ruqiah Ganda Putri Panjaitan

Department of Biology Education, Faculty of Teacher Training and Education, Tanjungpura University. JI. Prof. Dr. H. Hadari Nawawi, Bansir Laut, Kec. Pontianak Tenggara, Kota Pontianak, West Kalimantan 78124, INDONESIA.

E-mail: ruqiah.gpp@fkip.untan.ac.id History

- Submission Date: 15-05-2021;

- Review completed: 13-06-2021;

- Accepted Date: 28-06-2021

DOI : 10.5530/pj.2021.13.140

Article Available online

http://www.phcogj.com/v13/i5

\section{Copyright}

(C) 2021 Phcogj.Com. This is an openaccess article distributed under the terms of the Creative Commons Attribution 4.0 International license.

\begin{abstract}
Background: The red dragon fruit peel, which is rarely used in general, contains higher antioxidant properties compared to the flesh parts and has various secondary metabolites utilised in medicines. Objectives: This study was aimed to determine the effects of ethanol extract administration of the red dragon fruit peel (Hylocereus polyrhizus) against the decline of blood glucose levels in diabetes mellitus rats. Methods: In this study, the total of 24 male white Wistar rats (Rattus novergicus) were divided into 4 groups. All experimental animals were induced to diabetic conditions by the administration of streptozotocin and nicotinamide dosages at $45 \mathrm{mg} / \mathrm{kg}$ body weight and $110 \mathrm{mg} / \mathrm{kg}$ body weight, respectively. For 14 days, each group was treated accordingly. The first group or negative control (NC) was treated with the administration of CMC-Na $0.5 \%$ dose $2 \mathrm{ml} / 200 \mathrm{~g}$ body weight; the second group or positive control (PC) was administrated with glibenclamide dose $0.09 \mathrm{mg} / 200 \mathrm{~g}$ body weight; the third (E1) and fourth (E2) groups were administered with the ethanol extracts of the red dragon fruit peels at dosages of $37.44 \mathrm{mg} / 200 \mathrm{~g}$ body weight and $74.88 \mathrm{mg} / 200 \mathrm{~g}$ body weight, respectively. Results: After the 14-day trial, the average levels of blood glucose on the negative control group ( $382.92 \mathrm{mg} / \mathrm{dl}$ ) experienced no decline, and the blood glucose levels amongst groups were statistically different $(p<0.05)$. Conclusion: The anti-diabetic activity of the red dragon fruit peel in the ethanol extract dose $74.88 \mathrm{mg} / 200$ $\mathrm{g}$ body weight is statistically equal to the glibenclamide dose $0.09 \mathrm{mg} / 200 \mathrm{~g}$ body weight. Key words: Antidiabetic activity, Diabetic rats, Hylocereus polyrhizus.
\end{abstract}

\section{INTRODUCTION}

Diabetes mellitus is the leading cause in the developed countries and is one of the main health problems in the developing countries. ${ }^{1}$ Diabetes mellitus is typically a disease that requires longterm medications and outstanding costs, mainly for the purchase of synthetic drugs. In fact, the use of synthetic medicines generally has negative impacts, such as hypoglicemia, ${ }^{2}$ gastrointestinal disorders like nausea, ${ }^{2}$ flatulent ${ }^{3}$; even the negative impacts of long-term use can cause kidney problems. ${ }^{4-5}$ One of the methods to overcome the damaging collisions of the use of synthetic drugs is natural-based medicines, which can be used as an alternative choice in treating diabetes mellitus, which certainly have an anti-diabetic property. ${ }^{6-7}$

Relating to the anti-diabetic activities, some studies have showed diverse plants that are effective of decreasing blood glucose levels, such as soursop leaf (Annona muricata) ${ }^{8}$; the combination of sirih merah leaf (Piper crocatum) with bawang dayak (Eleutherine palmifolia Merr)' ${ }^{9}$ Indonesian bay-leaf (Syzygium polyanthum) ${ }^{10}$; fenugreek seeds (Trigonella foenum-graecum) ${ }^{11}$; cinnamon (Cinnamomum zeylanicum) ${ }^{11}$; mangosteen skin (Garcinia mangostana Linn) ${ }^{12}(2)$; white dragon fruit (Hylocereus undatus) ${ }^{13-14}$; the red dragon fruit flesh (Hylocereus polyrhizus) ${ }^{15-16}$, and the red dragon fruit peel (Hylocereus polyrhizus). ${ }^{17}$

Several findings reported that dragon fruit also develops various medicinal properties. The flesh of red dragon fruit is effective as an antioxidant. ${ }^{18-20}$ Besides that, it has potential as cardioprotective, ${ }^{21}$ anti-cancer, ${ }^{20}$ antibacterial, ${ }^{22}$ anti-cholestrol, ${ }^{23}$ and anti-diabetic. ${ }^{16,19}$ The results revealed that the flesh of red dragon fruit contains abundance secondary metabolites, such as betacyanin ${ }^{24}$, flavonoid and phenolic ${ }^{6,24}$, alkaloid, saponin, and tannin. ${ }^{6}$

To this extent, the use of red dragon fruit is only on its flesh, whereas the peels weighting for about $30-35 \%$ of the total fruit mass are not optimally exploited. ${ }^{25}$ The phytochemical results demonstrated that the red dragon fruit peel contains some secondary metabolites, such as terpenoid ${ }^{26}$ and alkaloid. ${ }^{26,27}$ Moreover, it has contains tannin, steroid, and saponin $^{27,28}$, phenol hydroquinone, flavonoid, and triterpenoid. ${ }^{28}$ The red dragon fruit peel is reported to have higher antioxidant activities compared to the flesh. ${ }^{29,30}$ Previously, it was described that $1 \mathrm{mg} / \mathrm{ml}$ of red dragon fruit peel is effective of blocking free radicals of $83.48 \pm 1.02 \%$, whereas its flesh is merely capable of $27.45 \pm 5.03 \%{ }^{18}$ Furthermore, other studies relating to the red dragon fruit peel also mentioned that the administration of red dragon fruit peel-brewed water at $800 \mathrm{mg} / \mathrm{ml}$ may reduce blood glucose levels in rats. ${ }^{17}$

In the extraction process, the solvent is one of the essential parameters in the effectiveness of isolating bioactive compounds from a plant. ${ }^{31}$ According to Agustiningsih et al. $(2010)^{32}$, the use of ethanol $96 \%$ as a solvent can optimally bind phenolic and flavonoid compounds compared to water or another combination of water and ethanol $96 \%$. Accordingly, it is stated that the extraction process with the ethanol $96 \%$ solvent will produce an extract with a better total phenolic amount and antioxidant activity in comparison to extracts generated from a water solvent only. This is because ethanol is able to absorb more many compounds dissolved in a combination 
so that the extraction process with ethanol is more effective. ${ }^{33}$ Relating to amounts and chemical substances extracted from the process, it was conducted in this study to evaluate the antidiabetic effectiveness of the red dragon fruit peel in ethanol extracts against diabetes mellitus rats induced by streptozotocin-nicotinamide (STZ-NA).

\section{MATERIAL AND METHODS}

\section{Experimental animals}

A total of 24 Wistar male white rats aged 2 months with the body weights of 154-257 $\mathrm{g}$ was collected from the laboratory of The Centre for Food and Nutrition Studies, University of Gadjah Mada, Yogyakarta, Indonesia. Before the trial begun, all experimental animals were adapted to the treated environment for 7 days. During the acclimatisation, all were fed with standard diet of comfeed-branded AD-II (PT JAPFA) and drunk ad libitum. The health condition was also observed by weighting the body weight. The implementation of this study was approved by the Ethic Commission of Health Research RSUD Dr. Moewardi, Solo, Indonesia with the Ethical Clearance No. 1.108/X/HREC/2019.

\section{Extraction}

Red dragon fruits were collected from the local farmers in Bakau Besar Laut Village, Sungai Pinyuh District, Mempawah Regency, West Kalimantan, Indonesia. The 50-day ripened red dragon fruits after the flowers blossomed were harvested for $15 \mathrm{~kg}$ and selected for better quality ones. After that, all were cleansed with flowing water and dried. The separation of the peels and flesh was conducted, and it was obtained the total wet weight of $5.83 \mathrm{~kg}$. Next, the red dragon fruit peel was mashed using a blender and extracted by the maceration method. The extraction process referred to Putra's method $(2013)^{34}$. The mashed red dragon fruit peels were then placed into a maceration vessel and soaked with $16 \mathrm{~L}$ of the distilled ethanol $96 \%$. The extraction process was done $3 \times 24$ hours, and the extract solution was taken and stirred periodically for each 24 hours. The yield of red dragon fruit peels was filtered by filter papers, and the obtained filtrate was concentrated by rotary evaporator at $40^{\circ} \mathrm{C}$. The final extract was $30.01 \mathrm{~g}$ with a yield of $0.52 \%$.

\section{Manufacture of CMC-Na $0.5 \%$ solution}

CMC-Na $0.5 \%$ solution was made accordingly the method of Salma et al. $(2013)^{35}$, and the dosage was defined by the references of Saputri \& Zahara (2016) ${ }^{36} \mathrm{~A}$ total of $0.5 \mathrm{~g} \mathrm{CMC-Na} \mathrm{(Sigma-Aldrich)} \mathrm{was} \mathrm{poured}$ into a beaker glass and dissolved in $\pm 30 \mathrm{ml}$ warm aquades, then was homogenously unified. CMC-Na solution was then moved to a 100 $\mathrm{ml}$ volumetric flask till reached the threshold and stirred up until homogenous. CMC-Na $0.5 \%$ solution dose $2 \mathrm{ml} / 200 \mathrm{~g}$ body weight was induced to experimental rats.

\section{Manufacture of streptozotocin solution}

Production of streptozotocin solution and dosages correspondingly referred to Ghasemi et al. (2014). ${ }^{37}$ A total of $216 \mathrm{mg}$ streptozotocin (Cayman Chemical) was dissolved in $72 \mathrm{ml}$ buffer citrate with $\mathrm{pH} 4.5$ which was prepared beforehand injection. Then, the homogenisation was performed by using homogeniser. Streptozotocin dose used in inducing diabetes mellitus in rats was $45 \mathrm{mg} / \mathrm{kg}$ body weight.

\section{Manufacture of nicotinamide solution}

Nicotinamide solution dose $110 \mathrm{mg} / \mathrm{kg}$ body weight was produced following the method of Ghasemi et al. (2014). ${ }^{37}$ A total of $528 \mathrm{mg}$ nicotinamide (Sigma-Aldrich) was suspended in $72 \mathrm{ml}$ sodium chloride 0.9\% (PT Widrata Bhakti). Nicotinamide dose $110 \mathrm{mg} / \mathrm{kg}$ body weight was administrated to treated rats.

\section{Manufacture of glibenclamide suspension}

Production of glibenclamide suspension and dosage administration of $0.45 \mathrm{mg} / \mathrm{kg}$ body weight were correspondingly adopted from Salma et al. (2013). ${ }^{35}$ Glibenclamide dosage (PT Indofarma) for adults is $5 \mathrm{mg}$. Hence, the dosage used in rats is $5 \times 0.018=0.09 \mathrm{mg} / 200 \mathrm{~g}$ body weight. A glibenclamide tablet of $27 \mathrm{mg}$ was placed into mortar for grinding, then was dissolved in $15 \mathrm{ml}$ of CMC-Na $0.5 \%$ solution. Glibenclamide dosage administered to rats was $0.45 \mathrm{mg} / \mathrm{kg}$ body weight.

\section{Rat Models with diabetes mellitus type 2}

Experimental rats for diabetes mellitus type 2 were induced by using the combination of streptozotocin and nicotinamide dose $45 \mathrm{mg} / \mathrm{kg}$ body weight and $110 \mathrm{mg} / \mathrm{kg}$ body weight, respectively, in which was injected via intraperitoneal. Nicotinamide injection was given 15 mins before streptozotocin administration. ${ }^{37}$

\section{Activity test of the red dragon fruit peel extracts}

After all treated animals were adapted for 7 days, they were then randomly divided into 4 groups with each group of 6 rats. All rats were fasted for $\pm 8-12$ hours, and their blood was drawn for $0.5 \mathrm{ml}$ via sinus orbitalis to measure the preliminary level of blood glucose (day 0). Also, on the same day, all rats were injected with the STZNA combination doses $45 \mathrm{mg} / \mathrm{kg}$ body weight and $110 \mathrm{mg} / \mathrm{kg}$ body weight via intraperitoneal. Nicotinamide injection was made 15 mins earlier than streptozotocin. ${ }^{37}$ After 72 hours (day 3), the measurement of blood glucose level with STZ-NA induction was carried out. Rats are diagnosed with diabetes mellitus type 2 if the blood glucose levels $>200$ $\mathrm{mg} / \mathrm{dl} ;^{38}$ all rats used in this experimental study had blood glucose levels $>200 \mathrm{mg} / \mathrm{dl}$ after STZ-NA administration. Afterwards, the extract was introduced once a day via oral for 14 days. The first group as negative control (NC) was administrated with the CMC-Na $0.5 \%$ solution dose $2 \mathrm{ml} / 200$ g body weight; the second group as positive control (PC) was treated with glibenclamide dose $0.09 \mathrm{mg} / 200 \mathrm{~g}$ body weight; the third group was induced with the ethanol extract of red dragon fruit peel dose $37.44 \mathrm{mg} / 200 \mathrm{~g}$ body weight (E1); and the fourth group was injected with the ethanol extract of red dragon fruit peel dose $74.88 \mathrm{mg} / 200 \mathrm{~g}$ body weight (E2). The administration of ethanol extraction was initiated from day 4 to 17 . On day 18 , the blood was drawn back; yet, all rats were initially fasted for \pm 12 -15 hours before the blood draw.

\section{Measurement of blood glucose levels}

A $0.5 \mathrm{ml}$ blood sample was collected from sinus orbitalis using microhematocrit, then was inserted into eppendorf tube. The obtained blood sample was centrifuged at $4000 \mathrm{rpm}$ for 15 mins. After that, the separated blood serum was taken out of $10 \mu \mathrm{l}$ by microliter pipette and inserted into test tube. As a comparator, the standard test tube was added with $10 \mu$ l glucose standard FS (DiaSys). On the test tube with blood serum, it was added $1000 \mu \mathrm{l}$ glucose reagent (Glucose GOD FS DiaSys) and homogenised by vortex. After homogenisation, the sample absorbance test was performed by using spectrophotometer UV at $500 \mathrm{~nm}$. The results presented on the monitor were recorded on an observation sheet in $\mathrm{mg} / \mathrm{dl}$.

\section{Data analysis}

Overall, the data was statistically analysed using SPSS 24 for Windows. The data of average levels of blood glucose was then analysed using one-way analysis of variance, then was continued with the Duncan test at a confidence rate of $5 \%$.

\section{RESULTS AND DISCUSSION}

The measurement of blood glucose levels was done three times; the initial blood glucose levels or before STZ-NA induction, the 72 hours 


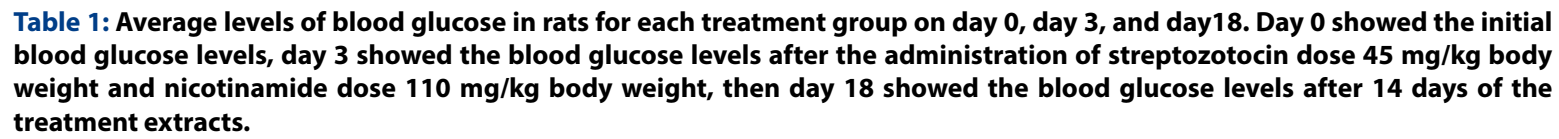

\begin{tabular}{cccc}
\hline \multirow{2}{*}{ Trial Group } & \multicolumn{3}{c}{ Average Levels of Blood Glucose (mg/dl) } \\
\cline { 2 - 4 } & Day 0 & Day 3 & $383.92^{\mathrm{c}} \pm 33.00$ \\
NC & $73.78^{\mathrm{b}} \pm 1.47$ & $379.80^{\mathrm{a}} \pm 30.87$ & $106.59^{\mathrm{a}} \pm 3.11$ \\
PC & $70.73^{\mathrm{a}} \pm 1.97$ & $389.20^{\mathrm{ab}} \pm 17.81$ & $140.62^{\mathrm{b}} \pm 5.63$ \\
E1 & $72.29^{\mathrm{ab}} \pm 2.42$ & $416.07^{\mathrm{b}} \pm 20.14$ & $109.17^{\mathrm{a}} \pm 2.60$ \\
E2 & $70.39^{\mathrm{a}} \pm 2.32$ & $401.13^{\mathrm{ab}} \pm 20.18$ &
\end{tabular}

Information:

$\mathrm{NC}=$ Negative Control (CMC-Na $0.5 \%$ solution dose $2 \mathrm{ml} / 200 \mathrm{~g}$ body weight $)$

PC = Positive Control (glibenclamide dose $0.09 \mathrm{mg} / 200 \mathrm{~g}$ body weight)

$\mathrm{E} 1=$ Administration of ethanol extract of the red dragon fruit peel dose $37.44 \mathrm{mg} / 200 \mathrm{~g}$ body weight

$\mathrm{E} 2=$ Administration of ethanol extract of the red dragon fruit peel dose $74.88 \mathrm{mg} / 200 \mathrm{~g}$ body weight

*Numbers shown after \pm demonstrated SD (standard deviation)

*Group followed by the same letters are not significantly different ( $p>0.05)$

blood glucose levels after STZ-NA induction, and overall blood glucose levels after the 14-day treatments. In the measurement of the initial blood glucose levels, all rats had normal rates; after STZ-NA injection, all blood glucose levels in rats increased; after the treatments for 14 days, the positive and extract-treated groups experience declines (Table 1).

Diabetes mellitus is a metabolic disorder with a sign of high glucose levels in blood, as a result of pancreatic impairment due to inactivity of producing insulin at optimal levels or our body is not able to use insulin effectively. The decline in the functions of pancreas as an insulin producer causes disruptions in the metabolism of carbohydrates, lipids, and proteins which can lead to hyperglycaemia condition. Therefore, one of the methods that can be done to diagnose diabetes mellitus is by measuring blood glucose levels.

Based on Table 1, it was seen, on day 0 (before STZ-NA induction), the blood glucose levels in the experimental rats were normal (70.39-73.78 $\mathrm{mg} / \mathrm{dl})$. Following with Wolfenshon \& Lloyd (2013), ${ }^{39}$ it was stated that the blood glucose levels in fasting rats are approximately $50-135 \mathrm{mg} / \mathrm{dl}$. Furthermore, this study reported that on day 3 ( 72 hours after STZ-NA induction), the blood glucose levels in the treated rats were above 200 $\mathrm{mg} / \mathrm{dl}$, ranging from $379.80-416.07 \mathrm{mg} / \mathrm{dl}$, which indicated that all rats were diabetes mellitus. In accordance with Anwer (2014) ${ }^{38}$; Nurhidajah \& Nurrahman(2016) ${ }^{40}$ it was demonstrated that blood glucose levels would be $>200 \mathrm{mg} / \mathrm{dl}$ after 72 hours STZ-NA administration, and it can be claimed that rats were in diabetes mellitus type 2 already.

Streptozotocin is a compound which works by forming highly reactive free radical exposure so that can cause damages to cell membranes, proteins, and DNAs, including disruptions in insulin production in pancreatic $\beta$-cells. Streptozotocin (STZ, 2-deoxy-2-(3-(methyl-3nitrosoureido)-D-glucopyranose) can enter cytoplasm of pancreatic $\beta$-cells through glucose transporter 2 (GLUT 2) which exists on plasma membranes. ${ }^{41-42}$ Glucose group on streptozotocin structure which activates toxic effects on streptozotocin is more selective against pancreatic $\beta$-cells, and this can easily make streptozotocin entering pancreatic $\beta$-cells because they are more active seizing glucose compared to other cells. ${ }^{43}$ After entering, streptozotocin will trigger DNA alkylation. ${ }^{42,44}$ Methylnitrosurea from streptozotocin structure is responsible for toxicity activity owned by streptozotocin over the formation of methyl carbonium ions $\left(\mathrm{CH}^{3+}\right)$, which is extremely reactive producing methylation and DNA fragmentation. ${ }^{37}$ The incoming streptozotocin is then metabolised by cells and becomes a donor for the formation of nitric oxide (NO) which contributes to cell damages within the increased activity and the release of free radicals. ${ }^{45}$ This emerges the binding of reactive oxygen in mitochondria, inhibition of Krebs cycle, and degeneration of oxygen consumption in mitochondria, cutback of ATP production and nucleotides in pancreatic $\beta$-cells, ${ }^{46}$ and eventually inhibition of secretion and insulin synthesis ${ }^{45}$ so that blood glucose levels cannot enter into cells appropriately and result in hyperglycaemia which lead to diabetes mellitus type $2 .{ }^{47}$

The administration of the combination of streptozotocin and nicotinamide can prevent from excessive hyperglycaemia and mortality in rats. Nicotinamide is an antioxidant derivate vitamin B3 (Niacin) which protects pancreatic $\beta$-cells from cytotoxic activity of streptozotocin in several mechanisms. ${ }^{37,48}$ Nicotinamide can stimulate the regeneration of pancreatic $\beta$-cells, the growth of Langerhans cells, and can block apoptosis reactions. Besides that, the nicotinamide administration before streptozotocin injection can act as an acceptor of methyl group so that can reduce the DNA methylation process in pancreatic $\beta$-cells. ${ }^{37}$

After the treatments for the 14 consecutive days from day 4 to 17 , it was recorded the decline of blood glucose levels in the groups of PC, $\mathrm{E} 1$, and E2, ranging from $106.59-140.62 \mathrm{mg} / \mathrm{dl}$; yet, it was conversely in NC. As stated by Dewi et al. (2016), ${ }^{49} \mathrm{CMC}-\mathrm{Na}$ is neutral, then the administration of CMC-Na solution in this study was not also adequately effective in inducing anti-diabetic activity, which marked in the decrease of blood glucose levels.

Glibenclamide is one of the sulfonylureas class drugs, which is commonly used for therapies in patients with diabetes mellitus type $2 .{ }^{50}$ Glibenclamide is used either in a single or combination medication that can lower blood glucose levels effectively. ${ }^{51}$ The mechanism action of glibenclamide is to increase the release of insulin hormone in Langerhans pancreatic $\beta$-cells. ${ }^{44}$ Sulfonylureas work by hindering $\mathrm{K}^{+}$channels from pancreatic $\beta$-cells through sulfonylurea receptors that block the channels of ATP-sensitive $\mathrm{K}^{+} .{ }^{52}$ This inhibition causes membrane depolarisation, and this condition will open Ca channels. While opening $\mathrm{Ca}$ channel, $\mathrm{Ca}^{2+}$ ions will enter into pancreatic $\beta$-cells, stimulate the granules containing insulin, and insulin secretion occurred via exocytosis. ${ }^{53}$

The red dragon fruit peels have been reported to develop a greater amount of phenolic in comparison with their flesh. ${ }^{29}$ This study suggested that the ethanol extract of the red dragon fruit peel was able to reduce blood glucose levels significantly. The effectiveness is related to the secondary metabolites contained in the filtrate extraction of the red dragon fruit peels. As also stated, the red dragon fruit peel holds various secondary metabolites ${ }^{26-28}$ and antioxidant property; ${ }^{29,30}$ 
the previous studies demonstrated that the brewed water of the red dragon fruit peel has anti-diabetic activity. ${ }^{17}$ The aim of ethanol extraction in this study was to ensure all the filtrates properly filtered and concentrated following the method of Agustiningsih et al. (2010), ${ }^{32}$ in which stated that the use of ethanol $96 \%$ as a solvent could bind optimally all compounds of phenolic and flavonoid in comparison with water or another solvent combination of water and ethanol $96 \%$. Likewise, Rivai et al. (2013) ${ }^{33}$ revealed that the extractions with ethanol $96 \%$ produce a better total amount of phenolic and antioxidant activity compared to water solvent. Ghasemzadeh \& Ghasemzadeh $(2011)^{54}$ exposed that the compounds of phenolic and flavonoid have a linier contribution upon antioxidant activities so that the higher amounts of phenol and flavonoid in an extraction, the better antioxidant activity. Not only that, the reduction of blood glucose levels in rats due to the administration of ethanol extract of the red dragon fruit peel also does a result of the antioxidant properties belong to the red dragon fruit peels; the previous studies reported that the ethanol extraction in the red dragon fruit peel has high antioxidant, which is flavonoid. ${ }^{27,28,55}$ Flavonoid plays a role in donating hydrogen atoms so that it will be oxidized and bound to free radicals, making them more stable. ${ }^{13}$ Aside from flavonoids, the red dragon fruit peel also comprises tannin. ${ }^{27-28}$ Tannin is a phenolic compound that acts as an antioxidant. ${ }^{56}$ The mechanism action of tannin as an antioxidant is to catch free radicals, to hinder the glucose absorption in intestinal, to induce the regeneration of pancreatic $\beta$-cells that impacts on adipose cells to strengthen the insulin activity, and to improve glucose intake in the blood through the activity of insulin mediator resulting in the reduction of glucose levels in blood. ${ }^{56}$

\section{CONCLUSION}

The ethanol extraction of the red dragon fruit peel may decline blood glucose levels in rats with diabetes mellitus, and the anti-diabetic activity of the red dragon fruit peel dose $74.88 \mathrm{mg} / 200 \mathrm{~g}$ body weight is statistically equal to glibenclamide dose $0.09 \mathrm{mg} / 200 \mathrm{~g}$ body weight.

\section{REFERENCES}

1. Nyarko BE, Amoah RS, Crimi A. Boosting diabetes and pre-diabetes detection in rural Ghana. F1000 Research. 2019;8:289-99. https:// doi.org/10.12688/f1000research.18497.2

2. Fitriyani, Supadmi W. Evaluasi adverse drug reaction antidiabetes berdasarkan algoritma naranjo di bangsal rawat inap RS PKU Muhammadiyah Yogyakarta periode Desember 2011-Januari 2012. Jurnal IImiah Kefarmasian. 2012;2(2):205-13. http://dx.doi. org/10.12928/pharmaciana.v2i2.670

3. Almasdy D, Sari DP, Suhatri, Darwin D, Kurniasih N. Evaluasi penggunaan obat antidiabetik pada pasien diabetes melitus tipe-2 di suatu rumah sakit pemerintah Kota Padang-Sumatera Barat. Jurnal Sains Farmasi Klinis. 2015;2(1):104-10. https://doi.org/10.29208/ jsfk.2015.2.1.58

4. ZazuliZ, Hendrayana T, Pratiwi B, Rahayu C. Analisis kesesuaian dosis pada pasien gangguan fungsi ginjal di suatu rumah sakit pendidikan di Kota Bandung. Acta Pharmaceutica Indonesia. 2017:42(1):42-9. https://www.researchgate.net/publication/342549342

5. Pandanwangi S, Zuniarto AA, Mubarok $\mathrm{H}$. Analisa drug related problems (DRPS) pasien gagal ginjal dengan komplikasi diabetes mellitus di RSUD X. Pharma Xplore. 2018;3(1):170-83. https://doi. org/10.36805/farmasi.v3i1.330

6. Ratimba K, Valen R, Tandi J. Uji aktivitas fraksi buah naga merah terhadap penurunan glukosa darah tikus yang diinduksi streptozotocin. Farmakologika Farmasi. 2019;16(1):35-47. https:// jfarma.org/index.php/farmakologika/article/view/50/39
7. Khamees AH, Fawzi HA, Sahib HB. Phytochemical investigation and assessment of the hypoglycemic activity of two herbal extracts from selected Iraqi medicinal plants in alloxan-stimulated diabetic rats: A comparative study. F1000 Research 2020;9:247-57. v1. https://doi.org/10.12688/f1000research.22788.1

8. Sovia E, Ratwita W, Wijayanti D, Novianty DR. Hypoglycemic and hypolipidemic effects of Annona muricata L. leaf ethanol extract. Int J Pharm Pharm Sci 2017;9(3):170-4. http://dx.doi.org/10.22159/ ijpps.2017v9i3.16402

9. Anggi $V$, Magfirah. The effect hypoglycemic of ethanol extract combination red betel leaf (Piper crocatum) and Dayak onion (Eleutherine palmifolia Merr) in streptozotocin-induced. Pharmacogn J 2019;11(6):1401-5. DOI: 10.5530/pj.2019.11.216

10. Widyawati T, Yusoff NA, Asmawi MZ, Ahmad M. Antihyperglycemic effect of methanol extract of Syzygium polyanthum (Wight.) leaf in streptozotocin-induced diabetic rats. Nutrients 2015;7:7764-80. DOI:10.3390/nu7095365

11. Sharma S, Mishra V, Srivastava N. Protective effect of Trigonella foenum-graecum and Cinnamomum zeylanicum against diabetes induced oxidative DNA damage in rats. Indian J Biochem Biophys. 2020;57:15-26. http://op.niscair.res.in/index.php/IJBB/article/ view/31772

12. Taher M, Tg Zakaria TMFS, Susanti D, Zakaria ZA. Hypoglycaemic activity of ethanolic extract of Garcinia mangostana Linn. in normoglycaemic and streptozotocin-induced diabetic rats. BMC Complement Altern Med. 2016;16(135):1-12. http://dx.doi. org/10.1186/s12906-016-1118-9

13. Ajie RB. White Dragon Fruit (Hylocereus undatus) potential as diabetes mellitus treatment. Jurnal Majority. 2015;4(1):69-72. https://juke.kedokteran.unila.ac.id/index.php/majority/article/ view/503

14. Song $H$, Zheng $Z, W u ~ J$, Lai J, Chu $\mathrm{Q}$, Zheng $X$. White pitaya (Hylocereus undatus) juice attenuates insulin resistance and hepatic steatosis in diet-induced obese mice. PLoS One 2016;11(2):1-14. DOI:10.1371/journal.pone.0149670

15. Hadi NA, Mohamad M, Rohin MAK, Yusof MR. Effects of red pitaya fruit (Hylocereus polyrhizus) consumption on blood glucose level and lipid profile in type 2 diabetic subjects. Borneo Science. 2012;31:113-29. https://jurcon.ums.edu.my/ojums/index.php/ borneo-science/article/view/180

16. Hadi TI, Sulendri NKS, Luhtfiyah F, Aladhiana C. Pemberian buah naga (Hylocereus polyrhizus) terhadap penurunan kadar glukosa darah pasien DM di wilayah kerja puskesmas Tanjung Karang. Jurnal Gizi Prima. 2018;3(2):108-12. https://doi.org/10.32807/jgp. v3i2.116

17. Rahma DE, Adriaria M. Efek pemberian seduhan kulit buah naga merah (Hylocerheus polyrhizus) terhadap kadar glukosa darah tikus Sprague Dawley Hiperglikemia. J Nutr Coll. 2016;5(4):47583. https://doi.org/10.14710/jnc.v5i4.16461

18. Nurliyana R, Syed Zahir I, Mustapha Suleiman K, Aisyah MR, Kamarul Rahim K. Antioxidant study of pulps and peels of dragon fruits: A comparative study. Int Food Res J. 2010;17:367-75. https://www.researchgate.net/publication/283838723

19. Omidizadeh A, Yusof RM, Roohinejad S, Ismail A, Abu Bakar MZ, El-Din A. Bekhit A. Anti-diabetic activity of red pitaya (Hylocereus polyrhizus) fruit. RSC Adv. 2014;4(108):62978-86. DOI: 10.1039/ c4ra10789f

20. Guimaraes $D$ de $A B$, Castro $D$ dos $S B$ De, Oliveira FL De, Nogueira EM, Silva MAM da, Teodoro AJ. Pitaya Extracts induce growth inhibition and proapoptotic effects on human cell lines of breast cancer via downregulation of estrogen receptor gene expression. Oxid Med Cell Longev. 2017;1-13. https://doi. org/10.1155/2017/7865073 
21. Omidizadeh A, Yusof RM, Ismail A, Roohinejad S, Nateghi L, Bakar MZA. Cardioprotective compounds of red pitaya (Hylocereus polyrhizus) fruit. J Food, Agric Environ 2011;9(3\&4):152-6. https:// www.researchgate.net/publication/216034082

22. Tahera J, Feroz F, Das Senjuti J, Kanta Das K, Noor R. Demonstration of anti-bacterial activity of commonly available fruit extracts in Dhaka, Bangladesh. Am J Microbiol Res. 2014;2(2):6873. DOI:10.12691/ajmr-2-2-5

23. Werdiningsin W, Suhartati. Effects of red pitaya (Hylocereus polyrhizus) on Lipid Profile of Male White Rats (Rattus norvegicus) receiving high fat diet. Folia Medica Indonesia. 2018;54(1):16-21. DOI: $10.20473 /$ fmi.v54i1.8046

24. Nurul SR, Asmah R. Variability in nutritional composition and phytochemical properties of red pitaya (Hylocereus polyrhizus) from Malaysia and Australia. Int Food Res J. 2014;21(4):1689-97. https:// www.researchgate.net/publication/267031271

25. Faadlilah N, Ardiaria M. Efek pemberian seduhan kulit buah naga merah (Hylocereus polyrhizus) terhadap kadar HDL tikus Sprague Dawley dislipidemia. J Nutr Coll. 2016;5(4):280-8. https://doi. org/10.14710/jnc.v5i4.16422

26. Amalia $S$, Wahdaningsih $S$, Untari EK. Antibacterial activity testing of n-hexane fraction of red dragon (Hylocereus polyrhizus Britton \& Rose) fruit peel on Staphylococcus aureus ATCC 25923. Tradit Med J. 2014;19(2):89-94. https://doi.org/10.22146/tradmedj.8146

27. Noor MI, Yufita E, Zulfalina. Identifikasi kandungan ekstrak kulit buah naga merah menggunakan Fourier Transform Infrared (FTIR) dan fitokimia. Journal of Aceh Physics Society (JAcPS). 2016;5(1):14-6. https://media.neliti.com/media/publications/91926-ID-none.pdf

28. Manihuruk FM, Suryati T, Arief II. Effectiveness of the red dragon fruit (Hylocereus polyrhizus) peel extract as the colorant, antioxidant, and antimicrobial on beef sausage. Media Peternakan. 2017:40(1):47-54. https://doi.org/10.5398/medpet.2017.40.1.47

29. Fathordoobady F, Mirhosseini H, Selamat J, Manap MYA. Effect of solvent type and ratio on betacyanins and antioxidant activity of extracts from Hylocereus polyrhizus flesh and peel by supercritical fluid extraction and solvent extraction. Food Chem. 2016;202:7080. http://dx.doi.org/10.1016/j.foodchem.2016.01.121 FOCH

30. Niah R, Helda. Aktivitas antioksidan ekstrak etanol kulit buah naga merah daerah Pelaihari, Kalimantan Selatan dengan metode DPPH (2,2-difenil-1-pikrilhidrazil). Jurnal Pharmascience. 2016;3(2):36-42. https://garuda.ristekbrin.go.id/documents/detail/883309

31. Truong DH, Nguyen DH, Ta NTA, Bui AV, Do TH, Nguyen HC. Evaluation of the use of different solvents for phytochemical constituents, antioxidants, and in vitro anti-inflammatory activities of Severinia buxifolia. J Food Qual. 2019;2019:1-9. https://doi. org/10.1155/2019/8178294

32. Agustiningsih, Wildan A, Mindaningsih. Optimasi cairan penyari pada pembuatan ekstrak daun pandan wangi (Pandanus amaryllifous Roxb) secara maserasi terhadap kadar fenolik dan flavonoid total. Jurnal Momentum. 2010;6(2):36-41. DOI:10.36499/jim.v6i2.118

33. Rivai $H$, Widya $S$ E, Rusdi. Pengaruh perbandingan pelarut etanolair terhadap kadar fenolat daun sirsak. Jurnal Sains dan Teknologi Farmasi. 2013;18(1):35-42. https://garuda.ristekbrin.go.id/ documents/detail/621413

34. Putro W. Daya peredam radikal bebas ekstrak etanol buah pepino putih dan ungu (Solanum muricatum Aiton var Putih dan Ungu) Terhadap DPPH (1,1-Diphenyl-2-Picrylhydrazyl). Jurnal IImiah Mahasiswa Universitas Surabaya. 2013;2(2):1-8. https://www. neliti.com/publications/19764

35. Salma N, Paendong J, Momuat LI, Togubu S. Antihiperglikemik ekstrak tumbuhan suruhan (Peperomia pellucida [L.] Kunth) terhadap tikus wistar (Rattus norvegicus L.) yang diinduksi sukrosa. Jurnal Ilmiah Sains. 2013;13(2):116-22. https://doi.org/10.35799/ jis.13.2.2013.3055
36. Saputri FC, Zahara R. Uji aktivitas anti-inflamasi minyak atsiri daun kemangi (Ocimum americanum L.) pada tikus putih jantan yang diinduksi karagenan. Pharm Sci Res. 2016;3(3):107-19. DOI: 10.7454/psr.v3i3.3619

37. Ghasemi A, Khalifi S, Jedi S. Streptozotocin-nicotinamide-induced rat model of type 2 diabetes. Acta Physiol Hung. 2014;101(4):40820. DOI: 10.1556/APhysiol.101.2014.4.2

38. Anwer T. Melatonin ameliorates hyperinsulinemia, glucose intolerance and insulin resistance in STZ-nicotinamide induced type 2 diabetic rats. Int J Pharm Pharm Sci. 2014;6(2):133-6. : https:// www.researchgate.net/publication/262143107

39. Wolfenshon S, Lloyd M. Handbook of Laboratory Animal Management and Welfare. 4th ed. Oxford: Blackwell Publishing, Ltd; 2013.

40. Nurhidajah N, Nurrahman N. Efek hipoglikemik kecambah beras merah pada tikus yang diinduksi STZ-NA dengan parameter kadar insulin, indeks HOMA-IR dan HOMA $\beta$. Agritech. 2016;36(4):433-9. https://doi.org/10.22146/agritech.16767

41. Szkudelski T. The mechanism of alloxan and streptozotocin action in B cells of the rat pancreas. Physiol Res. 2001;50(6):537-46. https://europepmc.org/article/med/11829314

42. Lenzen S. The mechanisms of alloxan- and streptozotocin-induced diabetes. Diabetologia. 2008;51(2):216-26. DOI: 10.1007/s00125007-0886-7

43. Husna F, Suyatna FD, Arozal W, Purwaningsih EH. Model hewan coba pada penelitian diabetes. Phar Sci Res. 2019;6(3):131-41. DOI: $10.7454 /$ psr.v6i3.4531

44. Chika A, Yahaya A. Effect of coadministration of glibenclamide and methanolic stem extract of Anisopus mannii N.E.Br. (Apocynaceae) on glucose homeostasis and lipid profile in streptozotocin/ nicotinamide-induced diabetic rats. Natl J Physiol Pharm Pharmacol. 2019;9(10):1045-51. DOI: 10.5455/njppp.2019.9.0829205092019

45. Saputra NT, Suartha IN, Dharmayudha AAGO. Agen diabetagonik streptozotocin untuk membuat tikus putih jantan diabetes mellitus. Buletin Veteriner Udayana. 2018;12(10):116-21. DOI: 10.24843/ bulvet.2018.v10.i02.p02

46. Lestari IC. Efek antidiabetik ekstrak etanol daun mahkota dewa (Phaleria macrocarpa) pada tikus diabetes yang diinduksi streptozotosin. Biomedika. 2018;10(2):94-101. DOI: https://doi. org/10.23917/biomedika.v10i2.7019

47. Muhammad AA. Resistensi insulin dan disfungsi sekresi insulin sebagai faktor penyebab diabetes melitus tipe 2. Jurnal Kesehatan Masyarakat. 2018;8(2):173-8. DOI: 10.31934/promotif.v8i2.631

48. Muhlishoh A, Wasita B, Patriado Nuhriawangsa AM. Antidiabetic effect of Centella asiatica extract (whole plant) in streptozotocin nicotinamide-induced diabetic rats. Indonesian J Nutr Diet 2018;6:14-22.

49. Dewi NP, Allia R, Sabang SM. Uji efektivitas antidiabetes Eleutherine bulbusa (MILL.) URB. terhadap penurunan kadar glukosa darah tikus obesitas. Prosiding Nasional Tumbuhan Obat Indonesia Ke-50;2016 April 20-21; Samarinda:Indonesia; 2016. https://doi.org/10.25026/ mpc.v3i2.88

50. Hikmah N, Yuliet, Khildah K. Pengaruh pemberian ekstrak daun salam (Syzygium polyanthum Wight.) terhadap glibenklamid dalam menurunkan kadar glukosa darah mencit (Mus musculus) yang diinduksi aloksan. Galenika J Pharm. 2016;2(1):24-30. https://doi. org/10.22487/j24428744.2016.v2.i1.5300

51. Duppala V, Dash RP, Jivrajani MN, Thakur SK, Ravat NM, Nivsarkar M. Simultaneous quantification of glibenclamide, simvastatin, and quercetin by using LC-UV method and its application to pharmacokinetic study in rats. Chromatogr Res Int. 2013;2013:1-6. https://doi.org/10.1155/2013/768160 
52. Lamprianou S, Gysemans C, Saab JB, Pontes H, Mathieu C, Meda P. Glibenclamide prevents diabetes in NOD Mice. PLoS One. 2016;11(12):1-16. DOI:10.1371/journal. pone.0168839

53. Muliawan IKDI. Efek pemberian kombinasi jus aloe vera dan glibenklamid terhadap penurunan kadar glukosa darah pada model tikus diabetes yang diinduksi dengan streptozotosin dan nikotinamid. Intisari Sains Medis. 2019;10(2):527-31. DOI: 10.15562/ism. v10i2.532
54. Ghasemzadeh A, Ghasemzadeh N. Flavonoids and phenolic acids: Role and biochemical activity in plants and human. J Med Plant Res. 2011;5(31):6697-703. DOI: 10.5897/JMPR11.1404

55. Tenore GC, Novellino E, Basile A. Nutraceutical potential and antioxidant benefits of red pitaya (Hylocereus polyrhizus) extracts. J Funct Foods. 2012;4:129-36. DOI:10.1016/j.jff.2011.09.003

56. Kumari M, Jain S. Tannins : An antinutrient with positive effect to manage diabetes. Res J Recent Sci. 2012;1(12):70-3. http://www. isca.in/rjrs/archive/v1/i12/14.ISCA-RJRS-2012-113.php

\section{GRAPHICAL ABSTRACT}

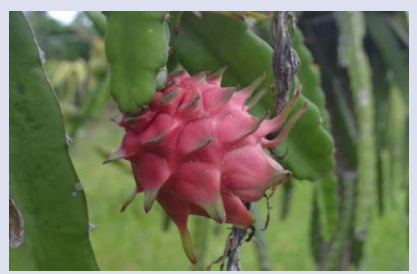

Anti-Diabetic Activity

Average levels of blood glucose in rats on each treatment group on the day 0,3 , and 18

\begin{tabular}{|c|c|c|c|}
\hline \multirow{2}{*}{ Trial Group } & \multicolumn{3}{|c|}{ Average Levels of Blood Glucose (mg/dl) } \\
\hline & Day 0 & Day 3 & Day 18 \\
\hline NC & $73.78^{b} \pm 1.47$ & $379.80^{a} \pm 30.87$ & $383.92^{c} \pm 33.00$ \\
\hline PC & $70.73^{a} \pm 1.97$ & $389.20^{\mathrm{ab}} \pm 17.81$ & $106.59^{a} \pm 3.11$ \\
\hline E1 & $72.29^{\mathrm{ab}} \pm 2.42$ & $416.07^{b} \pm 20.14$ & $140.62^{b} \pm 5.63$ \\
\hline E2 & $70.39^{a} \pm 2.32$ & $401.13^{a b} \pm 20.18$ & $109.17^{a} \pm 2.60$ \\
\hline \multicolumn{4}{|l|}{ Information: } \\
\hline \multicolumn{4}{|c|}{$\begin{array}{l}\mathrm{NC}=\text { Negative Control (CMC-Na } 0.5 \% \text { solution dose } 2 \mathrm{ml} / 200 \mathrm{~g} \text { body we } \\
\mathrm{PC}=\text { Positive Control (glibenclamide dose } 0.09 \mathrm{mg} / 200 \mathrm{~g} \text { body weight) }\end{array}$} \\
\hline \multicolumn{4}{|c|}{$\begin{array}{l}\text { E1 = Administration of ethanol extract of the red dragon fruit peel dose } 37.44 \mathrm{mg} / 200 \mathrm{~g} \text { body weight } \\
\text { E2 = Administration of ethanol extract of the red dragon fruit peel dose } 74.88 \mathrm{mg} / 200 \mathrm{~g} \text { body weight } \\
\text { * Numbers shown after } \pm \text { demonstrated SD (standard deviation) } \\
\text { *Group followed by the same letters are not significantly different ( } p>0.05 \text { ) }\end{array}$} \\
\hline
\end{tabular}




\section{ABOUT AUTHORS}

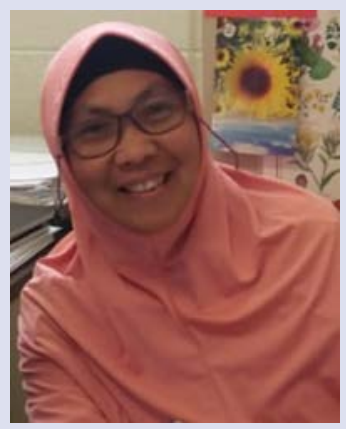

Ruqiah Ganda Putri Panjaitan, graduated from the Department of Biology, FMIPA Andalas University, Padang. She got her masters and doctorates from the Department of Biology FMIPA Bogor Agricultural University. Her field of interest is the study of medicinal plant activity. Now, she is working as a lecturer in Tanjungpura University.

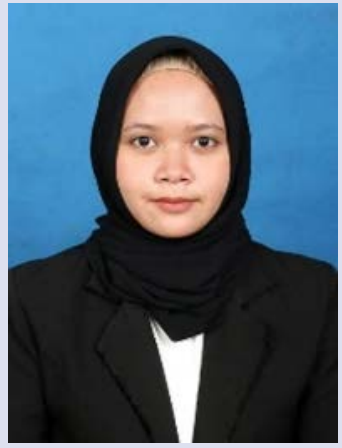

Novitasari, S.Pd., graduated from Department of Biology Education, Tanjungpura University in 2020. Her field of expertise is a Biology Education.

Cite this article: Panjaitan RGP, Novitasari. Anti-diabetic Activity of the Red Dragon Fruit Peel (Hylocereus polyrhizus) in Ethanol Extract against Diabetic Rats. Pharmacogn J. 2021;13(5): 1079-1085. 